\title{
Family presence in the firm's capital and external auditor choice: Evidence from French listed firms
}

\author{
Salma Damak Ayadi ${ }^{\mathrm{a}, 1}$, Rahma Ben Salem ${ }^{\mathrm{b}}$ and Asma Abdouli ${ }^{\mathrm{c}}$ \\ ${ }^{a}$ IHEC Carthage, University of Carthage, LIGUE, University of Manouba, \\ Tunisia \\ ${ }^{b} I S I G$, University of Kairouan, LIGUE, University of Manouba, Tunisia \\ ${ }^{c}$ University of Carthage, Tunisia
}

\begin{abstract}
Research question: The study investigates the impact of family presence in the firm's capital on the demand for audit quality. Motivation: The place occupied by family businesses in the world economy and the role of external auditors as a guarantor of the quality of financial information. Idea: Auditor choice is one of the most important decisions a firm has to make. It is an important external governance mechanism. This study shows the effect of family presence in the firm's capital on auditor choice. Data: In the study, a data set of 257 French listed firms during 2016 has been analysed. Tools: The study proposes a quantitative model based upon a binary logistic regression. Findings: Our results support that the family ownership structure is significantly and negatively related to the choice of higher-auditor quality. These results have allowed us to conclude that French family listed firms are less likely to appoint higher quality auditors. In summary, we find that family presence negatively affects the demand for audit quality.
\end{abstract}

Keywords: family presence, audit quality, Top 10 French audit firms, family firms.

JEL codes: M41

\footnotetext{
${ }^{1}$ Corresponding author: Salma Damak Ayadi, Full Professor, IHEC Carthage, University of Carthage, Tunisia, Member of the LIGUE LR99ES24, ISCAE, University of Manouba, Email: salmadamak@yahoo.fr
} 


\section{Introduction}

Despite previous studies showing that managerial firms dominate the global economic climate, several recent studies show that this form of business is the exception rather than the rule in most world countries and that family business are dominant. The study by La Porta et al. (1999) forms a major contribution in the literature that shows the dominance of these companies worldwide.

We chose to study this type of business from a corporate governance point of view, since this concept has always been the subject of several debates since its emergence. We focus especially on the external audit given its importance as an external corporate governance mechanism.

There is no academic consensus on the family business definition, and a scanning of the literature reveals a large number of definitions. Following the prior studies (Ali et al., 2007; Beldi et al., 2014), we define family firms as: "any firm whose capital is held by the same family at more than $50 \%$ for unlisted firms and $10 \%$ for listed firms, or those in with one or more members of the family managing the firm, or have transmitted the management to other generations of the family." (Ali et al. 2007)

Research on family businesses has only increased since the 1980s. In fact, family businesses have been perceived as a replication of non-family businesses. According to Astrachan (2010: 6), "if ever a field needed greater attention and more outlets for theory and research, family business is it". Compared to nonfamily firms, family firms face less severe agency problems that arise from the separation of ownership and management (Type I agency problems). However, they are characterised by more severe agency problems that arise between controlling and non-controlling shareholders (Type II agency problems) (Gilson \& Gordon, 2003).

In our study, we are interested in corporate governance and in particular in external audit and its quality within family businesses. Our choice is based, on the one hand, on the basis of the importance and specificities of these companies and on the other hand, on the basis of the role played by the auditor in certifying the reliability and credibility of the information financial. The relationship between family ownership structure and the choice of external auditor has been the subject of a number of previous researches (ElGhoul et al., 2007; Niskanen et al., 2010, 2011a, 2011b; Francis et al., 2009; Dey et al., 2011; Ho \& Kang, 2013; Khan et al., 2015; Darmadi, 2016; Hsua et al., 2017), the vast majority of which have found that family businesses are less likely to appoint better auditors. 
The primary objective of this study was to identify the influence of the family presence in the capital of the company on the choice of the external auditor in the French context. We chose to conduct our study in the French context because of the place occupied by family businesses in France and the specifics of the audit regulations in this country. The remainder of the paper is organised as follows: The first section presents a theoretical background, a review of prior literature and a development of our hypotheses. The second section provides a discussion of the sample and research methodology. The third section presents the empirical results, and the final section summarises the concluding remarks.

\section{Theoretical background}

\subsection{Agency theory}

Studies focusing on the corporate governance are dominated by agency theory. According to this theory, there is a conflictual relationship between the shareholders (the principal) and the managers (the agent), since the separation between their functions certainly generates an information asymmetry and an interests divergence. The agency relationship is characterised, in most cases, by interest conflicts between its parts. In fact, the agent acts in his own interest in order to maximise his own wealth. This opportunism results from the information asymmetry existing between the principal and the agent. Given his involvement in the management, the agent has a higher information level than the principal, and has more information about the actual situation of the firm. This opportunistic behaviour requires the principal to pay agency costs through the use of corporate governance mechanisms in order to manage and resolve the interest conflicts and reduce the information asymmetry.

The traditional agency theory suggests that family firms, which are operating under a single owner-manager, can be considered as an example of agency conflict absence, and these firms, therefore, will have zero or insignificant agency costs (Gélinier, 1996). Family involvement can reduce the agency's problems (Jensen \& Meckling, 1976; Fama \& Jensen, 1983). According to Dalton and Daily (1992), family firms are considered as "the most efficient form of organization". But the family is not a homogenous group with converging interests (Sharma et al., 1997). Family firms constitute a heterogeneous group of organisations and are not all identical. As a result, these firms may be particularly vulnerable to agency conflicts. The agency theory, thus, offers a rich reference framework for studying the particular problems of family businesses (Chrisman et al., 2004). The presence of a founding family significantly influences agency conflicts in two opposite ways: the alignment effect and the entrenchment effect. 


\subsection{Stewardship theory}

The stewardship theory, proposed by Donaldson (1990), represents an alternative model of agency theory. It is based on another vision of human behaviour and, in fact; the stewardship relationship parts have less conflictual relationships. The stewardship theory states that the primary goal of managers is to provide a good quality work, and they never have interest conflicts with the shareholders (the principal).

According to this theory, the managers are trustworthy. In such cases, there is no need for control mechanisms because the interests of the principal and the steward are already aligned. In this situation, the control over the manager is only a counterproductive mechanism because it minimises his motivation. The stewardship theory was founded as a complement to the agency theory for studying the governance of family businesses (Lee et al., 2003).

\subsection{Literature review and hypotheses}

The aim of our research paper is to study the relationship between the family presence in the firm's capital and the choice of the external auditor in the French context. As an effective mechanism of corporate governance, external audit can mitigate agency conflicts, reduce information asymmetry and improve the financial statements credibility (Jensen \& Meckling, 1976; Cohen et al., 2002; Fan \& Wong, 2005; Leventis et al., 2010).

From an agency perspective, family ownership and control can either mitigate (alignment effect) or increase (entrenchment effect) agency conflicts. Family firms represent a unique organisational structure. There are two agency perspectives explaining the behaviour of family owners. First, the alignment effect predicts that the interests of managers and shareholders are better aligned in family firms than in nonfamily firms. This is because family owners hold a large block of shares, and, consequently, will be more strongly motivated to monitor managers to maintain the position and reputation of their company and ensure the longevity of the family dynasty (Miller et al., 2013). This leads to mitigating «Type I" agency problems. We, therefore, can note that the family represents a corporate governance mechanism and this helps in minimising the opportunistic behaviour of managers (Anderson et al., 2003; Ali et al., 2007)).

In contrast, the entrenchment effect predicts that conflicts of interest, between controlling family owners and other shareholders, will be high in family firms, because the more concentrated ownership and domination of top executive positions creates an incentive for family owners to expropriate a firm's assets for their private benefit (Shlefer \& Vishny, 1997; Claessens et al., 2002). Given the concentration of ownership and control in the hands of the family, "Type II" 
agency problems are dominant in this type of business. From this perspective, controlling family owners would act to discourage information flow related to firm activities, in order to conceal their own opportunistic behaviours. Consequently, the controlling family owners may be reluctant to appoint higher-quality auditors, because stricter monitoring, as imposed by the auditors, will reduce their discretion in fostering opacity regarding transactions that benefit themselves.

The distinctive characteristics of family businesses are expected to play an important role in the external auditor choice. Previous studies have examined the influence of family control on various corporate governance mechanisms, and suggested that the demand for audit quality depends on the level of information asymmetry and agency conflicts (Watts \& Zimmerman, 1983; Healy \& Palepu, 2001). However, we find that in the financial and accounting literature, there is an important number of studies about the choice of the external auditor and the determinants of this choice in several contexts. This question remains less investigated in the case of family businesses despite their predominance on the global economy. Using a large sample of firms from 13 Western European countries, El Ghoul et al. (2007) found that companies, in which the CEO or the chairman of the board belongs to the dominant family, are less likely to name better quality auditors.

Using a sample of small private firms in Finland, Niskanen et al. (2010) found that an increase in family ownership decreases the likelihood of hiring a "Big 4" auditor. In Europe, such a negative association has been reported by Francis et al. (2009) and Niskanen et al. (2011a), based on samples of French and Finnish firms. The selection of such external auditors is established to protect the shareholders' interests of the family. Based on a sample of American companies, Dey et al. (2011) proved the negative link between the family property structure and the external auditor quality. They suggested that the "Big4" might limit the discretionary behaviour of family members.

Ho and Kang (2013) investigated auditor choice and audit fees in family firms using data from S\&P 1500 companies in the USA. Their findings show that family firms in the USA tend to recruit lower quality auditors and incur lower audit fees. This is consistent with the "type I" agency conflicts regarding the prevalence of lower information asymmetry between owners and managers in family firms. Arifur et al. (2015) revealed this negative association between family presence and the external auditor quality in Bangladesh.

The study by Darmadi (2016) indicated that when the majority shareholder is a family, the demand for external auditor quality decreases because this type of firm is less likely to face information asymmetry problems given the alignment of interests between shareholders and managers. Hsua et al. (2017) also found similar results using a sample of listed firms in Taiwan. In fact, they indicated that, despite 
the presence of two different types of agency conflicts, family businesses are less likely to appoint better quality auditors.

Some studies have shown that family businesses are more likely to demand a higher audit quality than non-family businesses. According to Ang et al. (2000), family firms can appoint higher quality auditors to convince minority shareholders and potential investors of the financial information credibility. The study by Lei $e t$ al. (2018) about the impact of family control/ownership on auditor choice and audit fees in Hong Kong, indicated that family firms have a higher likelihood to appoint "Big 4" auditors to signify their incentives to reduce the agency problem, adopting sound corporate governance practices and also as a signal of credible financial reporting.

We note that the number of studies dealing with the relationship between family presence in the firm's capital and external auditor choice is low, and we can notice that the unanimity of these studies adopts the notion of Big / not Big in order to assess the quality of the external audit. From this literature review, the hypothesis is presented as follows: Family firms are less likely to hire "Top 10" audit firms than non-family firms in France.

\section{Methodology}

\subsection{Sample}

The purpose of this study is to examine the impact of family presence in the firm's capital on the choice of the external auditor. We chose to realise our study on the French context for two reasons. The first is the importance of family businesses in the economy of this country: According to the 2016 PwC "France Global Family Business" study, French family businesses are around 50,000 of the businesses apart from VSEs (very small businesses), and they represent $83 \%$ of businesses in France. In fact, one third of SMEs (small and medium-sized enterprises) and midcaps (medium-sized enterprises) are family businesses. These companies $27 \%$ of their capital for four generations or more $27 \%$ for three generations, $33 \%$ for two generations and $13 \%$ for a single generation. Among French family businesses 1,500 companies are centenarians and 180 companies are over 200 years old.

The second reason is the specificities of audit regulation in France: (1) The mission of the external auditor is governed by professional standards drawn up by the Compagnie Nationale des Commissaires aux Comptes (CNCC), and, subsequently, approved by the public authorities; (2) The disciplinary responsibility of auditors in the context of listed companies is subject to rigorous supervision, starting with the financial security law promulgated on August 1, 2003. (3) The civil liability of auditors in France is enshrined in civil law, and article 822-17 of the commercial 
code provides that "the statutory auditors are responsible, both with regard to the person or entity and third parties, of the damaging consequences of faults and negligence committed by them in the exercise of their functions." (4) The criminal liability of external auditors is explicitly provided for by French law (articles 820-6 and 820-7 of the commercial code). (5) The independence of auditors is also governed by French law that deals with the obligation to appoint a joint audit, the legal duration of the audit mandate and the formal prohibition of any combination of an audit mandate and advisory - missions. The initial sample contains all the French firms listed on the "CAC all-tradable ${ }^{i}$ ". The initial list consists of 272 companies (family and non-family). Due to a data availability problem, we reduced the sample in order to obtain a final sample of 257 French listed firms.

\subsection{Model}

A binary logistic regression method is used to determine the effect of the family presence in the firm's capital on the choice of the external auditor in the French context.

AUD $i=\beta 0+\beta 1 \mathrm{FAM}_{i}+\beta 2$ Indep.directors $_{i}+\beta 3$ Dualiy $_{i}+\beta 4$ Foreign subsidiary $_{i}+$

$$
+\beta 5 \text { Size }_{i}+\beta 6 \mathrm{ROA}_{\mathrm{i}}+\beta 7 \mathrm{LEV}_{\mathrm{i}}+\varepsilon \mathrm{i}
$$

$\beta=$ constant $; \mathrm{i}:$ Firm $\mathrm{i}$

$\mathrm{AUD}=1$ if the company is audited at least by a firm that belongs to the "Top 10" in France, 0 otherwise.

$\mathrm{FAM}=1$ if the company is a family business, 0 otherwise.

Indep.directors $=$ the number of independent directors / the total number of directors $* 100$.

Duality $=1$ if the chairman of the board is also the executive director.

Foreign subsidiary $=1$ if the company has foreign subsidiaries, 0 otherwise.

Size $=$ logarithm of total assets.

$\mathrm{ROA}=$ Net Income / total assets

$\mathrm{LEV}=$ total debts $/$ total assets.

$\varepsilon$ : residual error.

\subsection{Variables measurement}

\section{Dependant variable}

Auditor choice «AUD»: The audit firm size is the most used proxy to measure the external audit quality (DeAngleo, 1981; Krishnan et al., 2000; Kim et al., 2003; Kane \& Velury, 2004; Niemi, 2004; Lensberg et al., 2006; Li et al., 2008; Chang et al., 2008; Francis \& Yu, 2009; Ho \& Kang, 2013; Khan et al., 2015; Hsua et al., 2017). 
According to Simunic and Stein (1987), large audit firms offer better audit quality than small firms because they have better human and material resources and can attract competent and experienced employees. A large number of researchers have revealed a significant superiority of the "Big4" audit firms in the quality of the audit provided when compared to other firms (DeAngelo, 1981; Palmrose, 1988; Choi \& Pack, 1998). To explain this superiority, the accounting literature gives several arguments. The financial and human resources of the "Big4" are among the main explanations; in fact, they allow employee skills to develop (Francis \& Wilson, 1988; DeFond, 1992; Hay \& Davis, 2004; Fortin \& Pitman, 2007).The financial crisis of 2008 and the financial scandals of the beginning of the century have highlighted the failures of the audit process, especially the independence of external auditors and the reputation of the "Big" due to the involvement of one of these firms (Arthur Andersen) in the famous Enron affair.

In this study, we ignored the simple "Big / No Big" distinction and we considered the auditor's affiliation to the "Top 10" audit firms in France as a proxy of the audit quality. The "Top 10" group represents the major audit firms in France classified according to the turnover (Appendix 2).

The dependent variable in this study "AUD" reflects the external auditor quality. It is a binary variable equal to 1 if the firm is audited by one of the "Top 10" audit firms and 0 otherwise.

\section{Independent variables}

Variables of interests:

Family Property Structure "FAM": This variable indicates whether the firm is a family firm or a non-family firm. To identify the family firms, we have used the definition adopted by Ali et al. (2007) and Beldi et al. (2014): "Any firm whose capital is held by the same family at more than $50 \%$ for unlisted firms and $10 \%$ for listed firms, or those in with one or more members of the family managing the firm, or have transmitted the management to other generations of the family." It is a binary variable that takes the value 1 when the accumulation of shares held by family members exceeds $10 \%$ of the capital and at least one family member sits in the board of directors and 0 otherwise.

\section{Control variables:}

Proportion of independent directors on the Board of Directors: " Indep. directors": The board of directors represents one of the main corporate governance mechanisms. According to Anderson et al. (1993) and Watts and Zimmerman (1990), the control exercised by the board of directors over the firm's managers can influence decisions on the audit quality. Based on previous studies, we can note two essential board of directors characteristics that serve to fulfil its control role: the diligence and the independence. In our study, we are interested in the board members' independence analysed through the percentage of independent directors. It is equal to the number of independent directors / the total number of directors $* 100$. 
DUALITY: The literature review reveals a significant relationship between the combined roles of the Chairman of the Board and the Chief Executive Officer and the external audit quality. According to Makni et al. (2012), this duality has a positive impact on the external audit quality, which means that, in the presence of a functions combination of the CEO and the Chairman of the Board, firms request a high audit quality. It is a binary variable equal to 1 if the chairman of the board is also the executive director and 0 otherwise.

Foreign subsidiary: The international dimension also can affect the auditor choice. According to several studies, companies with a strong international commitment (having several subsidiaries abroad) are more likely to appoint higher quality auditors (Simunic et al., 1987; Beasley \& Petroni, 2001; Piot, 2011; Masmoudi, 2013). It is a binary variable that equals 1 if the company has foreign subsidiaries and 0 otherwise.

SIZE: Referring to previous studies, we can note that the firm's size is considered as an explanatory variable of the external auditor choice. In fact, large firms are more likely to appoint higher quality auditors. This variable equals to the logarithm of total assets.

The economic performance of the firm "ROA": According to the literature, the performance of the firm can affect the auditor choice. In fact, to highlight their performance, successful firms are more likely to appoint higher quality auditors. There is then a positive relationship between audit quality and firm performance (El-Ghoul, 2007; Lin \& Liu, 2009).In this study, we adopt the Return On Assets "ROA" as an indicator to measure the firm's performance. This measure was also used by Kane and Velury (2004) and Lennox (2005).

Leverage level "LEV": According to the literature, the leverage level can also influence the external auditor choice. Highly leveraged firms tend to confront shareholder-creditor agency conflict. Several researchers have indicated that the high leverage level will encourage firms to seek a high audit quality to reduce agency costs (Copley et al., 1995; Lee et al., 2003; Hay \& Davis, 2004). This variable is measured by the ratio of total debts to total assets. All the variable definitions and measurements are summarised in Appendix 3.

\section{Statistical Results}

\subsection{The descriptive analysis}

Table 1 summarises the descriptive statistics of dependent and independent variables that are included in this study. It shows that $93.4 \%$ of the companies in 
our sample appoint auditors ranked "Top 10" in France. Moreover, 65\% of the sampled firms belong to a family business and $35 \%$ are non-family firms.

Table 1. Descriptive statistics of dependent and independent variables

\begin{tabular}{cccc}
\hline & Variable & Number & Percentage \\
\hline \multirow{2}{*}{ AUD } & 0 & 17 & 6.6 \\
& 1 & 240 & 93.4 \\
& Total & 257 & 100 \\
\multirow{4}{*}{ FAM } & 0 & 167 & 65 \\
& 1 & 90 & 35 \\
& Total & 257 & 100 \\
\hline
\end{tabular}

Note: AUD is dummy encoded 1 if the firm is audited by one of the Top 10 audit firms and 0 otherwise, FAM is a dummy equal 1 for family firms, 0 otherwise.

Table 2 shows that the average of independent directors is equal to $46.984 \%$ with a minimum of $0 \%$ and a maximum of $100 \%$. Regarding the control variables, the average size of companies measured by the log of assets is 20.400 with a minimum of 12.381 and a maximum of 26.364. Moreover, the average leverage level is 0.601 . The firm's performance, measured by the ratio of net income to total assets, ranges between -1.061 and 0.532 with an average of $-0.021 .91 .8 \%$ of the sampled firms have foreign subsidiaries and in 58\% of the companies of our sample, the functions of the chairman of the board of directors and the executive director are performed by the same person.

Table 2. Descriptive statistics of control variables

\begin{tabular}{lccccc}
\hline $\begin{array}{c}\text { Continuous } \\
\text { Variable }\end{array}$ & N & Minimum & Maximum & Averge & $\begin{array}{c}\text { Standard } \\
\text { Deviation }\end{array}$ \\
\hline Indep. directors & 257 & 0 & 100 & 46.984 & 22.592 \\
SIZE & 257 & 12.381 & 26.364 & 20.400 & 2.549 \\
LEV & 257 & 0.77 & 2.672 & 0.601 & 0.261 \\
ROA & 257 & -1.061 & 0.532 & -0.021 & 0.192 \\
\hline
\end{tabular}

\begin{tabular}{lccc}
\hline \multicolumn{2}{c}{ Binary Variables } & Number & Percenta \\
\hline & 0 & 21 & 8.2 \\
Foreign & 1 & 236 & 91.8 \\
subsidiary & Total & 257 & 100 \\
& 0 & 108 & 42 \\
Duality & 1 & 149 & 58 \\
& Total & 257 & 100
\end{tabular}

Note: Indep. dire equal the proportion of independent directors, SIZE is the natural logarithm of year-end total assets., Foreign subsidiary is a dummy encoded 1 if the firm has 
foreign subsidiaries, 0 otherwise, LEV is the ratio of total debt to total assets, ROA is the ratio of net Income to total assets., Duality= is a dummy encoded 1 if the chairman of the board is also the executive director, 0 otherwise.

\subsection{Correlation Matrix}

The absence of multi-collinearity between the explanatory variables is a necessary condition that must be validated. Given the results reported in table 3, all Pearson correlation coefficients are below 0.7 (Evrard et al., 2003). Hence, there is no significant correlation between the explanatory variables, and, thus, there is no problem of multicollinearity.

Table 3. Pearson Correlation Matrix

\begin{tabular}{|l|c|c|c|c|c|c|c|}
\hline & Fam & $\begin{array}{c}\text { Indep. } \\
\text { directors }\end{array}$ & SIZE & $\begin{array}{c}\text { Foreign } \\
\text { subsidiary }\end{array}$ & LEV & ROA & Dualitw \\
\hline FAM & 1 & $-0.266^{* *}$ & 0.042 & 1.011 & -0.082 & $0.228^{* *}$ & -0.053 \\
\hline $\begin{array}{l}\text { Indep. } \\
\text { directors }\end{array}$ & $-0.266^{* *}$ & 1 & $0.164^{* *}$ & 0.026 & 0.021 & $-0.127^{*}$ & $-0.134^{*}$ \\
\hline $\begin{array}{l}\text { SIZE } \\
\text { Foreign }\end{array}$ & 0.042 & $0.164^{* *}$ & 1 & $0.136^{*}$ & $0.277^{* *}$ & $0.292^{* *}$ & 0.013 \\
\hline subsidiary & 0.011 & 0.026 & $0.136^{*}$ & 1 & 0.023 & 0.072 & 0.034 \\
\hline LEV & -0.082 & 0.021 & $0.277^{* *}$ & 0.023 & 1 & $-0.180^{* *}$ & 0.080 \\
\hline ROA & $0.228^{* *}$ & $-0.127^{*}$ & $0.292^{* *}$ & 0.072 & $-0.180^{* *}$ & 1 & 0.017 \\
\hline Duality & -0.053 & $-0.134^{*}$ & 0.013 & 0.034 & 0.080 & 0.017 & 1 \\
\hline
\end{tabular}

Note: FAMis a dummy equal 1 for family firms, 0 otherwise, Indep dire equal the proportion of independent directors, SIZEis the natural logarithm of total assets., Foreign subsidiary is a dummy encoded 1 if the firm has foreign subsidiaries, 0 otherwise, LEV is the ratio of total debt to total assets, ROA is the ratio of net Income to total assets., Duality= is a dummy encoded 1 if the chaiman of the board is also the executive director, 0 otherwise.

\section{Discussion of results}

In order to analyse the impact of family presence in the firm's capital on the choice of the external auditor, we applied a binary logistic regression on a sample of French listed companies (CAC all tradable) whose the dependent variable "AUD" indicates the quality of the external auditor of a given firm.

Table 4. Results of logistic regression

\begin{tabular}{lccccc}
\hline & B & E.S & Wald & SIG & $\operatorname{Exp(B)}$ \\
\hline FAM & -1.529 & 0.620 & 6.076 & $\mathbf{0 . 0 1 4} * *$ & 0,217 \\
$\begin{array}{l}\text { Indep. } \\
\text { directors }\end{array}$ & 0.28 & 0.012 & 5.009 & $\mathbf{0 . 0 2 5} * *$ & 1,028 \\
SIZE & 0.378 & 0.149 & 6.429 & $\mathbf{0 . 0 1 1} * *$ & 1,460 \\
Foreign & 0.396 & 0.878 & 0.203 & 0.652 & 1,486
\end{tabular}

Vol. 19, No. 2 
Family presence in the firm's capital and external auditor choice: Evidence from French listed firms

\begin{tabular}{|c|c|c|c|c|c|}
\hline \multicolumn{5}{|l|}{ subsidiary } & 0,413 \\
\hline ROA & -1.548 & 2.005 & 0.596 & 0.440 & 0,213 \\
\hline Duality & 0.450 & 0.564 & 0.636 & 0.425 & 1,568 \\
\hline \multicolumn{6}{|l|}{-2log likelihood } \\
\hline \multicolumn{2}{|l|}{$\begin{array}{l}\text { R-deux of Cox \& } \\
\text { Snell }\end{array}$} & \multicolumn{2}{|c|}{$9.5 \%$} & & \\
\hline $\begin{array}{l}\text { R-deux of } \\
\text { Nagelkerke }\end{array}$ & & \multicolumn{2}{|c|}{$24.5 \%$} & & \\
\hline \multicolumn{6}{|c|}{$\begin{array}{l}\text { Note: } * * \text { and } * * * \text { indicate that the coefficient is significant, respectively, at the thresholds } \\
\text { of } 5 \% \text { and } 1 \% \text {. FAM is a dummy equal } 1 \text { for family firms, } 0 \text { otherwise, Indep. dire equal } \\
\text { the proportion of independent directors, SIZE is the natural logarithm of total assets., } \\
\text { Foreign subsidiary is a dummy encoded } 1 \text { if the firm has foreign subsidiaries, } 0 \text { otherwise, } \\
\text { LEV is the ratio of total debt to total assets, ROA is the ratio of net Income to total assets., } \\
\text { Duality = is a dummy encoded } 1 \text { if the chairman of the board is also the executive director, } \\
0 \text { otherwise. }\end{array}$} \\
\hline
\end{tabular}

Table 4 shows that the explanatory variable namely "FAM" is significant at the rate of $5 \%(\beta=-1.529, \mathrm{Sig}=0.014<1)$. It has a negative relationship with the dependent variable "AUD"; it means that Family firms are less likely to hire "Top 10" audit firms than non-family firms in France, which confirms our hypothesis. This result is consistent with the studies of ElGhoul et al. (2007), Niskanen et al. (2010, 2011a, 2011b), Francis et al. (2009), Dey et al. (2011), Ho \& Kang (2013), Khan et al. (2015), Darmadi (2016) and Hsua et al. (2017).

As an explanation of this result, we argued that the choice of the external auditor depends on the level of agency conflicts in the firms and the way family businesses are characterised as detailed below. On the one hand, this is by the managers and shareholders' interests alignment, which result in a low level of a "Type I" agency conflict, and, consequently, a low demand for a higher external auditor quality. This idea is reinforced by the stewardship theory, which supposes that in this type of firm the managers are altruistic and trustworthy. In fact, they seek the well-being of their firms and they preserve the collective interest. On the other hand, by the opportunism of the majority shareholders who are always trying to maximise the wealth of their families, this increases the «Type II» agency conflicts. Although family entrenchment may create greater demand for higher-quality auditors, the dominant family owners are less likely to allow such a demand to be realised. We, therefore, can note that the family presence in the French listed firm's capital influences the external auditor choice in a significant way. In fact, the appointment of auditors belonging to the "Top 10" in France decreases with the family presence in the firm's capital.

Regarding the control variables, our results show that only the variables "Indep. directors" and "Size" have a significant relationship with he choice of the external 
auditor. The variable "Indep. directors" is significant at the rate of $5 \%$ and has a positive relationship with the dependent variable. This result is in line with the conclusions of O'Sullivan (2000), Beasley and Petroni (2001), Carcello et al. (2002), Lennox (2005), and Masmoudi (2013). It should be explained by the complementary relationship between the independence of the board of director's members and the external audit quality. In fact, the independent directors often ask for a better external audit quality to reinforce their own control and also to avoid any situation that may affect their legal responsibilities.

The variable "size" is significant at the rate $5 \%$ and has a positive relationship with the dependent variable. This result is consistent with results obtained by Lennox (2005), Fan \& Wong (2005), El-Ghoul (2007), Mitra et al. (2007), Beasley \& Petroni (2001), Abbott \& Parker, (2000), Guedhami et al. (2014), Darmadi (2016), and Hsua et al. (2017). Large firms have high visibility in the market, which makes the appointment of higher-quality auditors essential to maintain their reputation and increase stakeholder confidence.

As shown in Table 4, the $\mathrm{R}^{2}$ value is equal to $24.5 \%$. This means that the model explains $24.5 \%$ of the variance of the dependent variable. Table 5 summarises the results of this research.

Table 5. Summary of findings

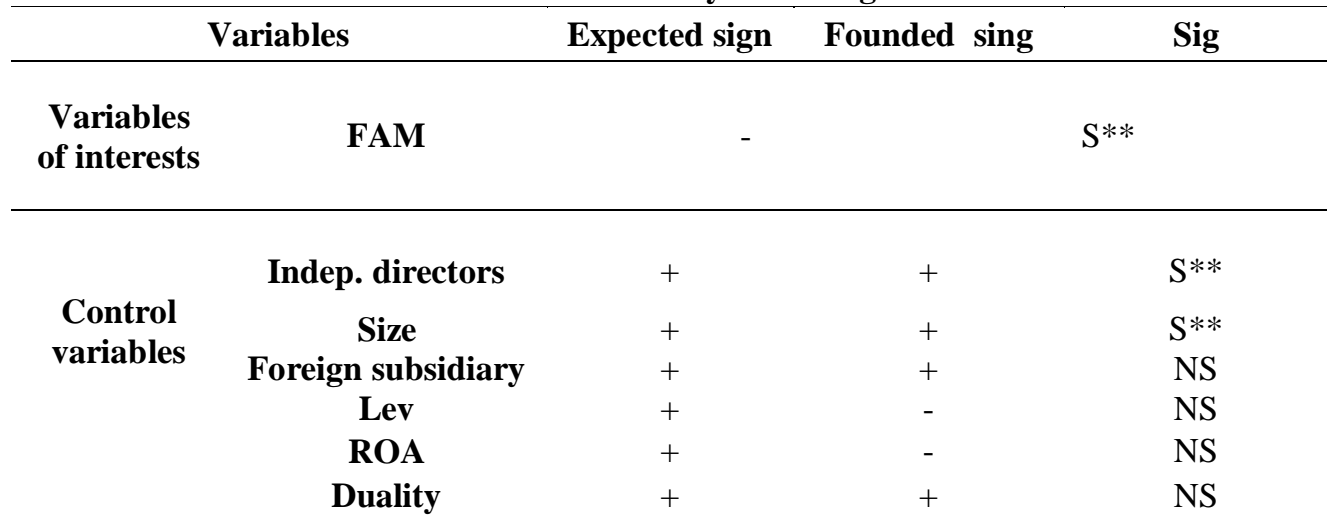

Note: S: significant, NS: no significant, FAM is a dummy equal 1 for family firms, 0 otherwise, Indep. dire equal the proportion of independent directors, SIZE is the natural logarithm of total assets., Foreign subsidiary is a dummy encoded 1 if the firm has foreign subsidiaries, 0 otherwise, LEV is the ratio of total debt to total assets, ROA is the ratio of net Income to total assets., Duality= is a dummy encoded 1 if the chairman of the board is also the executive director, 0 otherwise. 


\section{Conclusion}

Auditor choice is one of the most important decisions a firm has to make. It has significant implications for financial reporting transparency and quality. Despite abundant research on auditor choice, it remains an under-researched issue in family business. This paper provides a general analysis of the relationship between family presence in the firm capital and the demand for a better quality of external audit.

Based on a binary logistic regression, whose the dependent variable refers to the quality of the external auditor, the regression was applied to a sample of 257 listed French companies during 2016. The various tests lead to significant results with regard to the relationship between family presence in the firm's capital and the demand for audit quality. The results reveal that the company's family ownership structure has a significant and negative effect on the choice of the external auditor, which allows us to infer that family companies do not tend to appoint higherquality auditors. We can also conclude that listed French family firms are less likely to appoint auditors belonging to the "Top 10" in France. Thus, family presence effectively influences the external auditor choice and the demand for a better external audit quality.

Like any research work, we admit that there is the presence of certain limitations in our study, which may be addressed in the future. The audit environment differs from one country to another depending on the cultural and regulatory specificities of each country. This blocks the possibility to generalise our results. Conducting the study on a set of listed firms may represent another limitation. In fact, listed firms are governed by specific rules that are stricter than those of unlisted firms. Therefore, the appointment of good quality auditors can be a normal behaviour.

Finally, this paper could represent a starting point for future research. It would be interesting to realise the study in different contexts or even combine multiple countries in a single study. It is also possible to extend the samples to unlisted firms to analyse the different sizes and forms of companies.

\section{References}

Abbott, L. J. \& Parker, S. (2000) "Auditor selection and audit committee characteristics", Auditing: A Journal of Practice \& Theory, vol. 19, no. 2: 47-66

Adrian, C.H. Lei \& Samuel, W. K. Lam, (2018) "Family ownership, auditor choice and audit fees: evidence from Hong Kong", International Journal of Accounting and Financial Reporting, vol. 8, no.1 - page numbers?

Ali, A., Chen, T.Y. \& Radhakrishnan, S. (2007), "Corporate disclosures by family firms" Journal of Accounting and Economics, vol. 44, no.1-2: 238-286 
Anderson, D., Francis, J. R., \& Stokes, D. J. (1993), "Auditing, directorships and the demand for monitoring", Journal of Accounting and Public policy, vol. 12: 353-375.

Anderson, R. C. \& Reeb, D. M. (2003), "Founding-family ownership and firm performance: Evidence from the S\&P 500", Journal of Finance, vol. 58: $1301-1328$

Ang, J. S., Cole, R. A. \& Lin, J. W. (2000), "Agency costs and ownership structure", Journal of Finance, vol.55, no.1: 81-106

Astrachan, J. H. (2010), "Strategy in family business: Toward a multidimensional research agenda", Journal of Family Business Strategy, vol. 1, no. 1: 6-14

Beasley, M. S. \& Petroni, K. R. (2001) "Board independence and audit firm type", Auditing: A Journal of Practice and Theory, vol. 20, no. 1: 97-114

Beldi, A., Damak-Ayadi, S. \& Elleuch, A. (2014) "La divulgation volontaire sur le capital intellectuel: cas des entreprises familiales et non familiales en France", Revue de l'Entrepreneuriat, vol. 13, no. 3: 99-121

Carcello, J. V., Hermanson D. R., Neal, T. L., \& Riley, R. A. (2002) "Board characteristics and audit fees", Contemporary Accounting Research, vol. 19, no. 3: 365-384

Chang, X., Gygax, A.F., Oon, E. \& Zhang, F. (2008) "Audit quality, auditor compensation and initial public offering underpricinge", Accounting and Finance, vol. 48, no. 3: 391-416

Choi, K. \& Pack, W. (1998) "Auditor type and audit quality: Using audit fee and audit hours", Korean Accounting Review, vol. 35, no. 2: 49-75

Chrisman, J., Chua, J. \& Litz, R.A. (2004) "Comparing the agency costs of family and nonfamily firms: Conceptual issues and exploratory evidence", Entrepreneurship Theory and Practice, vol. 28: 335-354

Claessens, S., Djankov, S., Fan, J., \& Lang, L. (2002) "Disentangling the incentive and entrenchment effects of large shareholdings", Journal of Finance, vol. 57: 2741-2771

Cohen, J., Krishnamoorthy, G., \& Wright, A.M. (2002) "Corporate Governance and the Audit Process", Contemporary Accounting Research, vol. 19, no. 4: 573-594

Copley, P.A., Gaver, J.J. \& Gaver, K.M. (1995) "Simultaneous estimation of the supply and demand of differentiated audits: evidence from the municipal audit market", Journal of Accounting Research, vol. 33: 137-155

Dalton, D.R. \& Daily, C. M. (1992) "Financial performance of founder- managed versus professionally managed corporations", Journal of Small Business Economics, vol. 30: 25-34

Darmadi, S. (2016) "Ownership concentration, family control, and auditor choice: Evidence from an emerging market", Asian Review of Accounting, vol. 24, no.1: $19-42$

De Angelo, L.E. (1981) "Auditor size and audit quality", Journal of Accounting and Economics, vol. 3, no. 3: 183-199

Defond, M.L. (1992) "The association between changes in client firm agency costs and auditor switching", Auditing, vol. 11, no. 1: 16-31 
Dey, R. M., Hoi, C. K., \& Robin, A. (2011) "Family firms and auditor choice: a focus on IPO firms", working paper, Rochester Institute of Technology, Rochester

Donaldson, L. (1990) "The Ethereal Hand Organizational Economics and Management Theory", Academy of Management Review, vol. 15, no. 3: 369-381

El-Ghoul, S., Guedhami, O., Lennox, C., \& Pittman, J. A. (2007) "Ownership structure, agency problems, and auditor choice: evidence from Western European firms", working paper, University of Alberta, Edmonton, August.

Evrard, Y., Pras, B. \& Roux, E., Market. (2003) Etudes et recherche en Marketing, Dunod, Paris.

Fama, E.F. \& Jensen, M.C. (1983) "Separation of ownership and control", Journal of Law and Economics, vol. 26, no. 2: 301- 344

Fama, E. F. (1980) "Agency problems and the theory of the firm", Journal of Political Economy, vol. 78, no. 5: 228-307

Fan, Joseph P.H., \& Wong, T.J. (2005) "Do External Auditors Perform a Corporate Governance Role in Emerging Markets? Evidence from East Asia”, Journal of Accounting Research, vol. 43, no. 1: 35-72

Fortin, S. \& Pittman J. A. (2007) "The role of auditor choice in debt pricing in private firms", Contemporary Accounting Research, vol. 24, no. 3: 859-896

Francis J. R. \& Wilson Earl, R. (1988) "Auditor changes: A joint test of theories relating to agency costs and auditor differentiation", The Accounting Review, vol. 63 , no. 4: 663-682

Francis, J. R. (1984) "The effect of audit firm size on audit prices: A study of the Australian Market", Journal of Accounting and Economics, vol. 6: 133-151

Francis, J.R. \& Yu, M.D. (2009) "Big 4 Office Size and Audit Quality", The Accounting Review, vol. 48, no. 5: 1521-1552

Gélinier, O. (1996). La réussite des entreprises familiales : Les moyennes entreprises patrimoniales, un atout pour l'avenir. (3.ed.) Edition MAXIMA, Paris.

Gilson. R.J., Gordon. J., (2003) "Controllingcontrolling shareholders" Working Paper \# 228, Columbia Law School, TheCenter for Law and Economic Studies, New York.

Guedhami, O., Pittman, J. A., \& Saffar, W. (2014) "Auditor choice in politically connected firms", Journal of Accounting Research, vol. 52: 107-162

Hay David, \& Davis David. (2004) "The voluntary choice of an auditor of any level of quality", Auditing: A journal of practice \& theory, vol. 23, no. 2: 37-53

Healy, P. M. \& Palepu, K. G. (2001) "Information asymmetry, corporate disclosure, and the capital markets: A review of the empirical disclosure literature", Journal of Accounting and Economics, vol. 31, no. 1-3: 405-440

Ho, J. L. \& Kang, F. (2013) "Auditor choice and audit fees in family firms: evidence from the S\&P 1500", Auditing: A Journal of Practice \& Theory, vol. 32, no. 4: 71-93 
Hsua, H. and Lin, C.-H. \& Tsao, S.-M. (2017) "Founding family and auditor choice: evidence from Taiwan", Corporate governance: an international review, vol. 26, no. 2: 118-142

Jensen, M. C., \& Meckling W. H. (1976) "Theory of the firm: managerial behavior, agency costs and ownership structure", Journal of Financial Economics, vol. 3, no. 4: 305-360

Kane, G.D. \& Velury, U. (2004) "The role of institutional ownership in the market for auditing services: an empirical investigation", Journal of Business Research, vol. 57, no. 9: 976-983

Khan.A, Muttakin M.B \& Siddiqui.J, (2015) "Audit fees, auditor choice and stakeholder influence: Evidence from a family-firm dominated economy", The British Accounting Review, vol. 27: 304-320.

Kim, J., Chung, R. \& Firth, M. (2003) "Auditor conservatism asymmetric monitoring and earnings management", Contemporary Accounting Research, vol. 20, no. 2: 323-359

Krishnan, J. \& Schauer, P.C. (2000) "The differentiation of quality among auditors: Evidence from the. Not-For-Profit Sector", Auditing: A Journal of Practice and Theory, vol. 19, no. 2: 9-25

La porta, R., lopez-de-silanes F.L. \& Shleifer, A. (1999) "Corporate ownership around the world", Journal of Finance, vol. 52, no 2: 471-517

Lee, C., Rosenstein, S., Rangan, N. \& Davidson, W. (1992) "Board composition and shareholder wealth: the case of management buyouts", Financial Management, vol. 21: 58-72

Lee, P., Stokes, D., Taylor, S., \& Walter, T. (2003) "The association between audit quality, accounting disclosures and firm-specific risk: Evidence from initial public offerings", Journal of Accounting and Public Policy, vol. 22, no. 5: $377-400$

Lennox, C. (2005) "Management ownership and audit firm size", Contemporary Accounting Research, vol. 22, no. 1: 205-227

Lensberg, T., Eilifsen, A. \& McKee, T.E. (2006) "Bankruptcy theory development and classification via genetic programming", European Journal of Operational Research, vol. 9, no. 2: 677-697

Leventis, S. \& Dimitropoulos, P. E. (2010) "Audit pricing, quality of earnings and board independence: The case of the Athens stock exchange", Advances in Accounting, vol. 26, no. 2: 325-332

Li, C., Song, F.M. \& Wong, M.L. (2008) "A continuous relation between audit firm size and audit. opinions: evidence from China", International Journal of Auditing, vol. 12, no 2: 111-127

Lin, Z. J. \& Liu, M. (2009) "The impact of corporate governance on auditor choice: evidence from China", Journal of International Accounting, Auditing and Taxation, vol. 18, no. 1: 44-59

Makni, I., Kolsi, M. C., \& Affes, H. (2012) "The impact of corporate governance mechanisms on audit quality: evidence from Tunisia", The IUP Journal of Corporate Governance, vol. 11: 48-70 
Masmoudi A. W. (2013) "Mécanismes de gouvernance et qualité de l'audit externe : le cas français", La Revue Gestion et Organisation, vol. 5:183-195

Miller, D., Le Breton-Miller, I., \& Lester, R. H. (2013) "Family firm governance, strategic conformity, and performance: Institutional vs. strategic perspectives ", Organization Science, vol. 24:189-209

Mitra, S., Deis, D. R., \& Hossain, M. (2007) "The empirical relationship between ownership characteristics and audit fees", Review of Quantitative Finance and Accounting, vol. 28, no. 3: 257-285

Niemi, L. (2004) "Auditor size and audit pricing: evidence from small audit firms", European Accounting Review, vol. 13, no. 3: 71-101

Niskanen, M., Karjalainen, J., \& Niskanen, J. (2010) "The role of auditing in small, private family firms: is it about quality and credibility", Family Business Review, vol. 23, no. 3: 230-245

Niskanen, M., Karjalainen, J., \& Steijvers, T. (2011a) "Audit quality: the role of board structure in family firms", working paper, University of Eastern Finland, Kuopio, 13 June

Niskanen, M., Karjalainen, J., \& Niskanen, J. (2011b) "Demand for audit quality in private firms: evidence on ownership effects", International Journal of Auditing, vol. 15, no. 1: 43-65

O'Sullivan, N. (2000) "The impact of board composition and ownership on audit quality: evidence from large U K companies", British Accounting Review, vol. 32: 397-414

Palmrose, Z. (1988) "An analysis of auditor litigation and audit service quality", Accounting Review, vol. 63, no.1: 55-73

Piot, C. (2001) "Agency costs and audit quality: evidence from France", European Accounting Review, vol. 10, no. 3: 461-499

Sharma, P., Chrisman, J.J. \& Chua, J.H. (1997) "Strategic management of the family business: Past research and future challenges", Family Business Review, vol. 1: 1-35

Shlefer, A. \& Vishny, R. W. (1997) "A survey of corporate governance”, Journal of Finance, vol. 52:737-783

Simunic, D. \& Stein, M. (1987) "Product differentiation in auditing: auditor choice in the market for unseasoned new issues", Research Monograph $\mathrm{N}^{\circ} 13$ of The Canadian Certified General Accountants' Research Foundation.

Stewart, J. D. (1984) "The role of information in public accountability In Issues in public sector accounting, Hopwood, A. G. and Tomkins, C. (Eds.), Oxford: Philip Allan

Wang, D. (2006) "Founding family ownership and earnings quality", Journal of Accounting Research, vol. 44, no. 3: 619-656

Watts, R. L. \& Zimmerman, J. L. (1983) "Agency problems, auditing, and the theory of the firm: Some evidence", Journal of Law and Economics, vol. 26, no 2: 613-633

Watts, R., \& Zimmerman, J. (1990) "Positive accounting theory: a ten year perspective", Accounting Review, vol. 65, no. 1: 131-156 


\section{Appendix 1: Ranking of audit firms on the French market}

\begin{tabular}{|c|c|c|c|c|c|c|c|c|}
\hline \multirow[t]{2}{*}{ Audit firm } & \multirow[t]{2}{*}{$\begin{array}{l}\text { Information } \\
\text { date }\end{array}$} & \multicolumn{2}{|c|}{ Turnover } & \multirow[b]{2}{*}{ Growth } & \multicolumn{2}{|c|}{ Workforce } & \multirow[b]{2}{*}{$\begin{array}{l}\text { Correspondent } \\
\text { in France }\end{array}$} & \multirow{2}{*}{$\begin{array}{c}\text { Tumover } \\
\text { in } \\
\text { France } \\
\mathrm{M} €\end{array}$} \\
\hline & & $\begin{array}{c}\text { Million } \\
\text { of } \$ \\
14 / 15\end{array}$ & $\begin{array}{c}\text { Million } \\
\text { of } \$ \\
13 / 14\end{array}$ & & 2015 & 2014 & & \\
\hline Deloitte & $05 / 15$ & 35200 & 34200 & 1.03 & 225351 & 210400 & Deloitte & 1051 \\
\hline KPMG & $09 / 15$ & 24440 & 24820 & 0.98 & 173965 & 162031 & KPMG SA & 932 \\
\hline EY & $06 / 15$ & 28655 & 27369 & 1.05 & 211450 & 188292 & EY & 855 \\
\hline $\mathrm{PwC}$ & $06 / 15$ & 35356 & 33952 & 1.04 & 208109 & 195433 & PwC & 809 \\
\hline Mazars. & $08 / 15$ & 1424 & 1459 & 0.98 & 15462 & 14088 & Mazars. & 323 \\
\hline $\begin{array}{c}\text { Grant } \\
\text { Thomton } \\
\text { Intemational }\end{array}$ & $09 / 15$ & 4633 & 4729 & 0.98 & 42204 & 40197 & $\begin{array}{l}\text { Grant } \\
\text { Thomton }\end{array}$ & 164 \\
\hline $\mathrm{RSM}$ & $12 / 15$ & 4641 & 4391 & 1.06 & 38353 & - & Exce & 164 \\
\hline $\begin{array}{c}\mathrm{HBL} \\
\text { Intemational }\end{array}$ & $12 / 15$ & 1910 & 1890 & 1.01 & 21201 & 18708 & HBL France & 135 \\
\hline $\begin{array}{l}\text { Baker Tilly } \\
\text { Intemational }\end{array}$ & $06 / 15$ & 3807 & 3563 & 1.07 & 27986 & 26846 & $\begin{array}{c}\text { Baker Tilly } \\
\text { France }\end{array}$ & 119 \\
\hline $\mathrm{BDO}$ & $09 / 15$ & 7304 & 7022 & 1.04 & 64303 & 59428 & BDO France & 111 \\
\hline $\begin{array}{c}\text { Crowe } \\
\text { Horwath } \\
\text { Intemational }\end{array}$ & $12 / 15$ & 3507 & 3436 & 1.02 & 33207 & 31040 & $\begin{array}{c}\text { Crowe } \\
\text { Horwath } \\
\text { Intemaional }\end{array}$ & 103 \\
\hline
\end{tabular}

(Source: profession comptable, April 2016) 
Family presence in the firm's capital and external auditor choice:

Evidence from French listed firms

Appendix 2: Operationalization of research variables

\begin{tabular}{|c|c|c|}
\hline Variable & \multicolumn{2}{|l|}{ Operationalization } \\
\hline \multicolumn{3}{|c|}{ Dependent variable } \\
\hline $\begin{array}{l}\text { Auditor } \\
\text { choice } \\
\text { «AUD» }\end{array}$ & \multicolumn{2}{|c|}{$\begin{array}{l}\text { Used as a proxy for audit quality } \\
\text { Binary }=1 \text { if the firm is audited by one of the Top } 10 \text { audit firms and } 0 \\
\text { otherwise. }\end{array}$} \\
\hline \multicolumn{3}{|c|}{ Independent variables } \\
\hline & Interest variables & Expected sign \\
\hline FAM & $\begin{array}{l}\text { Indicates the presence of family control } \\
\text { Binary }=1 \text { if the firm is family-controlled and } 0 \\
\text { otherwise }\end{array}$ & - \\
\hline \multicolumn{2}{|r|}{ Control variables } & Expected sign \\
\hline $\begin{array}{l}\text { Indep. } \\
\text { directors }\end{array}$ & $\begin{array}{l}\text { Indicates the proportion of independent directors on } \\
\text { the Board of directors. } \\
=\text { the number of independent directors / the total } \\
\text { number of directors) } * 100 \text {. }\end{array}$ & + \\
\hline Duality & $\begin{array}{l}\text { Binary }=1 \text { if the chairman of the board is also the } \\
\text { executive director. }\end{array}$ & + \\
\hline $\begin{array}{l}\text { Foreign } \\
\text { subsidiary }\end{array}$ & $\begin{array}{l}\text { Indicates whether } 0 \text { the firm has foreign subsidiaries. } \\
\text { Binary }=1 \text { if the company has foreign subsidiaries, } 0 \\
\text { otherwise. }\end{array}$ & + \\
\hline Size & $\begin{array}{l}\text { Reflects the firm size. } \\
=\text { logarithm of total assets. }\end{array}$ & + \\
\hline ROA & $\begin{array}{l}\text { Returns on assets: reflects the economic } \\
\text { performance of the firm } \\
\text { = Net Income / total assets. }\end{array}$ & + \\
\hline LEV & $\begin{array}{l}\text { Indicates firm's leverage level } \\
=\text { total debts / total assets. }\end{array}$ & + \\
\hline
\end{tabular}

\footnotetext{
${ }^{\mathrm{i}}$ The CAC All-Tradable is a stock index of the Paris Stock Exchange, created on March 21, 2011.
} 